\title{
Теорія комунікації
}

\section{УДК 811.111'282.4(73)’42:32}

\section{Олена Гнатковська, Валерія Назарко \\ (Чернівці)}

\section{МОВНИЙ ПОРТРЕТ АМЕРИКАНЦЯ В ІНАВГУРАЦЙНИХ ПРОМОВАХ ПРЕЗИДЕНТІВ США}

У статті розглядаються лексичні, аксіологічні та синтаксичні особливості мовного портрету американия на матеріалі інавгураційних промов президентів США. Об 'єктом дослідження обрано номінації американців, які містять лексему American. Встановлюються діахронічні зміни мовного портрету протягом трьох періодів історї США: становлення нащуї, урбанізаџії та новітньої історії.

Ключові слова: лексичний портрет, мовна особистість, мовний nортрет, синтаксичний портрет, иүінності.

В статье рассматриваются лексические, аксиологические и синтаксические особенности языкового портрета американиа на материале инаугураиионных речей президентов США. Объектом исследования избраны номинации американцев, которые содержат лексему Атегісап. Устанавливаются диахронические изменения языкового портрета в течение трех периодов истории США: становления нации, урбанизащии и новейшей истории.

Ключевые слова: лексический портрет, синтаксический портрет, иенности, языковая личность, языковой портрет.

The article outlines lexical, axiological and syntactic features of the linguistic portrait of the American on the material of the inaugural speeches of the US presidents. These political speeches have a tremendous impact on the formation of the image and ideology of the nation and can potentially alter or motivate the behavior of their addressees. The linguistic portrait emerges as a result of the gradual description of the linguistic identity which in our case is marked by 
the ethno-cultural specificity stipulated by the picture of the world, the mentality and national character of one of the most powerful nations in the world. Nominations containing the lexeme American were selected as the object of research. American linguistic identity is considered as a collective ethnic identity represented by lexical nominations of the Americans with their values verbalized through contextual clues. Lexical portrait of the Americans in the inaugural speeches contains racial, social, age, gender, quantity, personality, local and temporal features determined while analysing the combinability of the aforementioned nominations. The syntactic portrait is modeled by means of frequency analysis of syntactic functions (subject, predicative, object or attribute) peculiar to the nominations of Americans in presidential inaugural speeches. Diachronic changes of the American linguistic portrait are considered over three periods of US history: nation in the making, urbanization and recent history.

Keywords: lexical portrait, linguistic identity, linguistic portrait, syntactic portrait, values.

Одним 3 ключових принципів сучасної лінгвістики $\epsilon$ антропоцентризм, який передбачає вивчення мовної особистості 3 різних точок зору. Саме це завдання ставить перед собою лінгвістична персонологія, теоретичні засади якої були закладені в 1980-х роках минулого століття Ю. М. Карауловим. Визначення мовної особистості, запропоноване вищеназваним науковцем, стало основоположним. На його думку, мовна особистість - це сукупість «здібностей та характеристик людини, які зумовлюють створення та сприйняття мовлення / текстів, які відрізняються а) ступенем структурно-мовної складності, б) глибиною та точністю відображення дійсності, в) певною цільовою спрямованістю» [3, c. 3].

Поширений в лінгвоперсонологіі метод мовного портретування грунтується на описі мовних портретів персонажів в літературознавстві. Мовний портрет вимальовується в результаті поступового опису мовної особистості відповідно до завдань дослідника. Зазвичай мовне портретування передбачає порівневе відтворення мовної системи особистості, спостереження за мовленнєвою поведінкою, як правило, наводяться 
біографічні відомості про мовну особистість, іноді портрет може репрезентуватися зразками текстів. Характеристика індивидуальних особливостей в мові суб'єкта поєднується 3 виокремленням типових для певної соціальної групи рис.

В. І. Карасик поділяє підходи до вивчення мовної особистості на 4 типи: 1) дослідження мовної особистості у психології, де розроблено безліч класифікацій характерів; 2) аналіз мовної особистості з позицій соціології з виділенням мовних індикаторів соціальної ідентичності; 3) вивчення мовної особистості культурологами, які моделюють лінгвокультурні типажі; 4) опис мовної особистості з позицій лінгвістики. Останнім часом набув поширення прагмалінгвістічний підхід, в рамках якого мовна особистість аналізується з точки зору дискурсу, в якому вона бере участь [2, с. 319].

Для вивчення феномену мовної особистості сучасна лінгвоперсонологія враховує три основні рівні абстракції: а) особистість як індивідуум й автор текстів; б) особистість як типовий представник мовної спільноти; в) особистість як представник людського роду [3, с. 6].

Наше дослідження присвячене особистості американця як типового представника нації та здійснюється в лінгвістичному аспекті. Його актуальність полягає в тому, що для мовного портретування обрано колективну етнічну мовну особистість однієї 3 наймогутніших націй у світі - американців, та інавгураційні промови президентів, які очолювали цю націю протягом всієї іï історії. Ці політичні промови мають величезний вплив на формування іміджу й ідеології нації та потенційно можуть змінювати або мотивувати поведінку громадян-адресатів. Відклавши сумніви та незгоди, народ слухає слова президента, який, приймаючи присягу, має можливість довірити землякам свою філософію управління, концепцію президентства та бачення майбутнього, щоб, за словами Ф. Рузвельта під час третьої інавгурації (1941р.), «пригадати, яким було наше місце в історії ...i знову відкрити, ким ми є, і ким ми можемо стати» [8, с. 294].

Етнокультурна специфіка мовної особистості зумовлена картиною світу, ментальністю та національним характером певного етносу. Параметрами опису мовного портрета етнічної мовної 
особистості вважаються універсальні параметри культур з огляду на вплив характеристик певної культури на комунікативну поведінку особистості. Т. Л. Гурульова вважає, що своєрідність когнітивної свідомості носія певної етнічної культури, опосередкована іiі переконаннями і цінностями, обумовлює специфіку комунікативної свідомості носія цієї культури, що і визначає його комунікативну поведінку і відмінності втілення його мовної особистості в мові [1, c. 197].

Аналіз англомовної особистості проводився у нечисленних дослідженнях, зокрема було здійснено аналіз мовного портрета англійської мовної особистості (М. Г. Корочкін, Т. Л. Гурульова), мовної поведінки носіїв англомовної культури (Г. В. Слізарова), лінгвокультурного аспекту американської мовної особистості (Н. В. Поспєлова), американської мовної особистості з позиції прототипового підходу (Т. Ю. Ма), культурно-антропологічного портрету сучасного американця (А. Шелякіна).

Мета нашого дослідження - визначити лексичні, аксіологічні та синтаксичні особливості мовного портрету американця в інавгураційних промовах президентів США в діахронії. Об'єктом дослідження стали лексеми-номінації американців, які у вказаних промовах містять іменник American або прикметник American у поєднанні з назвами особи, або назви особи разом 3 фразою of America, предметом - їх лексичні, оцінні та синтаксичні характеристики. Матеріал дослідження складається 3151 фрагменту 3 вищезазначеними номінаціями 358 інавгураційних промов.

Ідентичність особистості складається з численних соціальних особистостей, а в етнічно строкатих суспільствах на кшталт США етнічна ідентичність $є$ важливою складовою соціальної ідентичності [11, с. 791]. Етнічна ідентичність вважається складним, багатогранним та динамічним процесом [10, с. 271]. 3 точки зору соціально-психологічного та еволюційного розвитку, етнічна мовна особистість, як правило, охоплює почуття індивідів щодо їхньої етнічної групи (наприклад, позитивний вплив, гордість), а також ступінь залученості особи до процесу отримання знань про етнічну групу (тобто дослідження етнічної ідентичності) і усвідомлення того, який сенс має їхня етнічність в житті [12, с. 
C. Хантінгтон вважає, що американська національна ідентичність визначається прихильністю до американського політичного кредо - по суті, принципів Декларації незалежності та конституційних структур, призначених для їх втілення, - а також участю у тому, що він називає основною англо-протестантської культури. Остання включає не лише політичні переконання, але й «християнську релігію, протестантські цінності та мораль, трудову етику, англійську мову, Британські традиції права, справедливості та межі влади уряду i спадщину європейського мистецтва, літератури, філософії й музики» [7, с. 40]. Критики його точки зору стверджують, що американська національна ідентичність формується лише за допомогою кредо.

Т. Ю. Ма дослідила американську мовну особистість в культурно-історичному просторі США в ХХ ст. та встановила, що мотиваційний рівень американської мовної особистості існує як діалектична єдність лінгвокультурних опозицій «Північ / Південь», «Захід / Схід», які визначають внутрішні мотиви і рушійні сили розвитку особистості, процеси сприйняття і породження текстів [4, c. 79]. Основні риси американського характеру та прототипні риси носія мови - індивідуалізм, волелюбність, впевненість у власних силах, наполегливість і діловитість, спрямованість у майбутне, - актуалізувалися в національних лінгвокультурних типажах жителів Півночі США. Цінності, властиві південній культурній традиції, - сім'я, минуле, війна, гостинність, честь і доблесть - розглядалися як варіантні і нерідко сприймалися як лакунарні фрагменти картини світу [4, с. 78].

Американці «дбають про інтереси своєї країни так, як про свої власні» і «мають почуття до своєї батьківщини, аналогічні тим, що відчуває чоловік до своєї родини» [9, с. 77]. Досліджуючи американську мовну особистість у лінгвокультурологічному контексті, Н. В. Поспєлова приходить до висновку, що американська багатогранність заснована на етнічному різноманітті, разом 3 тим, американці - єдина нація, якій властива етнічна монолітність. Характерними рисами американців $є$ індивідуалізм та самостійність: дух індивідуалізму пронизує практично всі аспекти американського життя. Американська нація, заснована 
шукачами пригод, вигнанцями, фанатиками, до цих пір зберегла дух непохитної самостійності. Спільними рисами першопрохідців є почуття шляху, дорога на океан, фронтири, мрії, непосильні глобальні завдання. Внаслідок цього сучасним американцям притаманні бажання рухатися вперед й перемагати та відсутність осілості [5, с. 137]. У дослідженні Т. Л. Гурульової англійська мовна особистість характеризується зосередженістю на співрозмовнику, вирішенні проблеми або результаті, ризикованістю, оптимізмом, неформальністю спілкування, акцентуванням моментів згоди зі співрозмовником, рішучістю, ефективністю i продуктивністю спілкування та ін. [1, с. 202].

В межах нашого дослідження мовного портрету американця усі лексеми-номінації американців в інавгураційних промовах були розподілені за трьома основними періодами:

1. Становлення нації (1789-1877 рр.) - період активної територіальної експансії, розвитку економіки і зростання внутрішніх суперечностей. У цей час завершилося становлення американської держави, яка політично балансувала між вільною північчю і рабовласницьким півднем, які змагалися за швидкозростаючий Захід, що стало найважливішою передумовою Громадянської війни.

2. Урбанізація США (1877-1945рр.) поєднувала кризу американської ідентичності з швидким економічним розвитком i потоком винаходів, які змінювали життя американців. Це була епоха небаченого економічного зростання, появи суспільства споживання та масової культури, яка завершилася найсерйознішою економічною кризою в історії США - Великою депресією - та вступом США у Другу світову війну.

3. У період новітньої історії (1945-) США вступили в холодну війну з СРСР і низку конфліктів в Азії. Ця епоха відзначилася боротьбою за цивільні права афроамериканців, що в свою чергу стимулювало посилення боротьби за свої права жінок, етнічних груп та інших меншин. США поступово перетворилися на єдину наддержаву з безпрецедентним політичним впливом та економічним зростанням.

Кількісний аналіз номінацій американців протягом цих періодів відображений у таблиці 1. 
Таблиця 1

Номінації американцій в інавгураційних промовах президентів США

\begin{tabular}{|c|c|c|c|}
\hline Період історії & $\begin{array}{c}\text { Становлення } \\
\text { нашії }\end{array}$ & Урбанізація & $\begin{array}{c}\text { Новітня } \\
\text { історія }\end{array}$ \\
\hline American(s) & 1 & 11 & 78 \\
\hline American people & 13 & 16 & 12 \\
\hline American citizen(s) & 5 & 5 & \\
\hline the people of America & 4 & & \\
\hline nations of America & 1 & & \\
\hline American subjects & 1 & & \\
\hline American freemen & 1 & & 2 \\
\hline citizens of America & & & 93 \\
\hline American workers & & & \\
\hline Рaзом & 26 & 32 & \\
\hline
\end{tabular}

Дані таблиці свідчать про те, що у період становлення нації використовувалася найбільш різноманітні номінації із суттєвим переважанням словосполучення American people, що складає рівно половину номінацій. В наступні періоди розмаїття номінацій значно зменшилося, що вказує на уніфікацію номінацій американців в інавгураційних промовах. У періодурбанізаціїпродовжує домінувати словосполучення American people, однак у період новітньої історії однозначно превалює іменник American, тим самим демонструючи тенденцію до індивідуалізації американського суспільства.

В результаті аналізу сполучуваності цих номінацій було виокремлено основні риси мовного портрету американця в інавгураційних промовах. У період становлення нації ними виявилися расові (the aboriginal nations of America [8, с. 12]), соціальні (their American subjects [8, с. 95]), гендерні (as American freemen we can ... [8, c. 117]) та особистісні ознаки (free American citizens [8, с. 95]). До расових (The negroes are now Americans [8, c. 235]) та особистісних характеристик (every thoughtful American [8, c. 198]) у період урбанізації додалилися квантитативні (And yet we are not the less Americans on that account [8, c. 247]) та темпоральні (Americans of today [8, с. 298]). Окрім усіх вищезазначених рис інавгураційні промови періоду новітньої історії додають до мовного портрету вікові (young Americans [8, с. 329]; an older American [8, 
c. 377]) та локальні характеристики (every American here and every American in our land [8, c. 402]).

Етнічну мовну особистість неможливо повністю зрозуміти без аналізу контексту $[13$, с. 22], відповідно контекстуальний аналіз фрагментів інавгураційних промов 3 номінаціями американців надасть можливість встановити основні ціннісні орієнтири американців за періодами. Згідно з попередніми дослідженнями, цінності, які найчастіше звучали в інавгураційнх промовах, це свобода, віра в Бога, патріотизм, справедливість, особиста відповідальність та мир. Істина / чесність частіше згадується у 19 столітті, а мужність - у 20 столітті [14, с. 126].

Наш аналіз показав, що до головних цінностей періоду становлення нації належать честь (honor), чесність (integrity, truth), права (rights), єднання (union), справедливість (justice, equity) та впевненість (confidence). У період урбанізації увага акцентується на таких цінностях як свобода (freedom, liberty, liberated), демократія (democracy, free government, self-government), верховенство права (law, law-abiding, lawful rights), честь (honor), віра (faith, God), мудрість (wisdom), сміливість (courage), рішучість (resolve, determination), підприємництво (enterprise) та бережливість (thrift, prudential economies).

А. Шелякіна серед основних характеристик сучасних американців як нації виділила «прагматизм, практичність, жагу до матеріального благополуччя, працьовитість, впевненість у собі, патріотизм та побожність, економічну та особистісну свободу, дієвість» [6, с. 217]. Миз'ясували, що у періоді новітньої історії визначальними цінностями американців є свобода (free, freedom, liberty), рівність (equal, equals), віра в Бога (faith, God), сміливість (courage, courageously, brave), мир (реасе), життя (life), рішучість (resolve, determination), можливості (opportunity), сила (strength, strong), відповідальність (responsibility, duty, obligation), робота (work), прогрес (progress, move forward, do better), енергійність (energy, action), зміна (change, renewal), надія (hope, hopeful), щастя (happy, happiness), гідність (dignity), закон (law), справедливість (just, justice), добро (good, goodness), права (rights) та досягнення (achievement, compete and win).

Синтаксичний портрет американця в інавгураційних промовах змодельовано на основі аналізу синтаксичних функцій номінацій 
американців. В процесі аналізу було виокремлено чотири синтаксичні функції властиві об'єкту дослідження:

1. Підмет, наприклад: The American people have encountered together great dangers and sustained severe trials with success [8, c. 42].

2. Додаток, наприклад: He has been pleased to favor the American people with opportunities for deliberating in perfect tranquility ...[8, c. 5].

3. Означення, репрезентоване of-фразою 3 номінаціями, наприклад: ... and most compatible with the mission of the American people [8, с. 180].

4. Іменна частина складного присудка, наприклад: ... we are all Americans pledged to carry on this last, best hope of man on Earth [8, c. 377].

Лише у період новітньої історії досліджувані номінації стали використовуватися як звертання, яке є граматично незалежним членом речення, наприклад: And so, my fellow Americans, at the edge of the 21st century, let us begin with energy and hope, with faith and discipline, and let us work until our work is done [8, c. 395].

Співвідношення проілюстрованих вище синтаксичних функцій за періодами відображено у діаграмі на рис. 1.

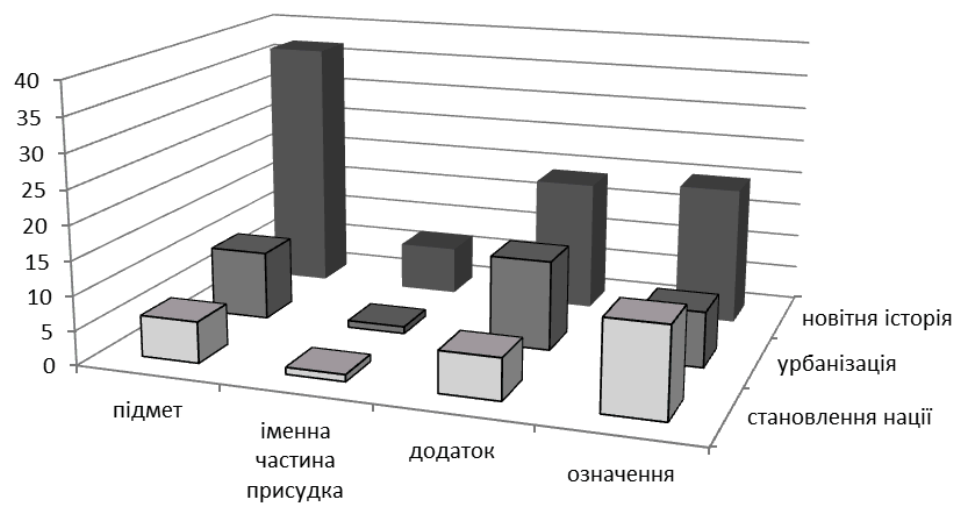

Рис. 1. Синтаксичні функції номінацій американців в інавгураційних промовах президентів США 
Як бачимо, синтаксичному портрету американця в інавгураційних промовах у період становлення нації притаманна домінуюча роль означень, які вказують на приналежність чогось американцям. Крім того чітко видно, що у період новітньої історії панівна роль належить підмету, тобто американці спочатку поступово, а потім різко перетворюються на виконавців дії. Також 3 кожним наступним періодом помітне зростання номінацій американців з функцією іменної частини складного присудка та додатку. Однак варто зазначити й те, що частотність функції додатку та означення в період новітньої історії майже рівнозначна, а частотність функції означення найнижча у період урбанізації.

Проведене дослідження дозволило нам прийти до таких висновків: основу лексичного портрету американця в інавгураційних промовах у періоди становлення нації та урбанізації складає уявлення про американців як народ, у період новітньої історії панує дух індивідуалізму. Досліджуваний мовний портрет містить расові, соціальні, гендерні та особистісні ознаки у період становлення нації; расові, особистісні, квантитативні та темпоральні характеристики у період урбанізації; усі вищеперераховані та вікові і локальні ознаки у період новітньої iсторії. 3 цього випливає, що расові та особистісні ознаки властиві мовному портрету протягом кожного з досліджуваних періодів. У синтаксичному портреті спостерігається поступове зміщення акценту 3 описового відображення американців за допомогою означень до діяльнісного - за допомогою підметів.

Перспективи подальшого дослідження вбачаємо у мовному портретуванні американців шляхом детального аналізу лексичних, аксіологічних та синтаксичних особливостей інших лексемномінацій американців в інавгураційних промовах президентів США.

\section{Список літератури}

1. Гурулева Т. Л. Речевой портрет этнической языковой личности (сопоставительная характеристика китайской, русской и английской языковых личностей). Культура и циивилизация. 2017. № 3. С. 196-205.

2. Карасик В. И. Языковые ключи. М.: Гнозис, 2009. 406 с. 
3. Караулов Ю. Н., Красильникова Е. В. Русская языковая личность и задачи ее изучения. Язык и личность. М.: Наука, 1989. С. 3-10.

4. Ма Т. Ю. Исследование американской языковой личности с позиций прототипического похода. Вестник Челябинского государственного университета. 2014. № 16. Филология Искусствоведение. Выпуск 91. С. 74-81.

5. Поспелова Н.В. Американская языковая личность в лингвокультурологическом контексте. Филологические науки. Вопросы теории и практики. Тамбов: Грамота, 2013. № 3. C. 136-138.

6. Шелякіна А. Культурно-антропологічний портрет сучасного американця: мовні засоби репрезентації. Гуманітарна освіта в технічних вищих навчальних закладах. № 27, Київ, 2013. С. 212221.

7. Huntington S. Who Are We?: The Challenges to America's National Identity. New York: Simon and Schuster, 2004. 428 p.

8. My Fellow Citizens: The Inaugural Addresses of the Presidents of the United States, 1789-2009. NY: Facts On File, 2010. 428 p.

9. Onuf P. S. American Exceptionalism and National Identity. American Political Thought. 2012. Vol. 1, No. 1. P. 77-100.

10.Phinney J. S., Ong A. D. Conceptualization and measurement of ethnic identity: Current status and future directions. Journal of Counseling Psychology. 2007. Vol. 54. P. 271-281.

11. Umana-Taylor A. J. Ethnic identity. Handbook of identity theory and research. New York, NY: Springer, 2011. P. 791-809.

12.Umana-Taylor A. J., Yazedjian A., Bamaca-Gomez M. Y. Developing the ethnic identity scale using Eriksonian and social identity perspectives. Identity: An International Journal of Theory and Research. 2004. № 4. P. 9-38.

13.Umaña-Taylor, A. J. Ethnic identity research: How far have we come? Studying ethnic identity: Methodological and conceptual approaches across disciplines. Washington, DC: American Psychological Association, 2015. P. 11-26.

14. Values Extolled in U.S. Presidential Inaugural Addresses / Richard T. Kinnier et al. Counseling and Values. 2004.Vol. 48. P. 126-130. 


\section{References transliterated}

1. Guruleva T. L. Rechevoj portret jetnicheskoj jazykovoj lichnosti (sopostavitel'naja harakteristika kitajskoj, russkoj i anglijskoj jazykovyh lichnostej). Kul’tura i civilizacija. 2017. № 3. S. 196-205.

2. Karasik V. I. Jazykovye kljuchi. M.: Gnozis, 2009. 406 s.

3. Karaulov Ju. N., Krasil'nikova E. V. Russkaja jazykovaja lichnost' i zadachi ee izuchenija. Jazyk i lichnost'. M.: Nauka, 1989. S. 3-10.

4. Ma T. Ju. Issledovanie amerikanskoj jazykovoj lichnosti s pozicij prototipicheskogo pohoda. Vestnik Cheljabinskogo gosudarstvennogo universiteta. 2014. № 16. Filologija Iskusstvovedenie. Vypusk 91. S. 74-81.

5. Pospelova N.V. Amerikanskaja jazykovaja lichnost ${ }^{6} \quad \mathrm{~V}$ lingvokul'turologicheskom kontekste. Filologicheskie nauki. Voprosy teorii i praktiki. Tambov: Gramota, 2013. № 3. C. 136-138.

6. Shelyakina A. Kul turno-antropologichnyj portret suchasnogo amerykancya: movni zasoby reprezentaciyi. Gumanitarna osvita v texnichnyh vyshhyh navchalnyh zakladah. \# 27, Kyyiv, 2013. C. 212-221. 